\title{
János Ede SZILÁGYI* \\ The Protection of the Interests of Future Generations in the 10-Year-Old Hungarian Constitution, With Special Reference to the Right to a Healthy Environment and Other Environmental Issues**
}

\author{
Abstract
}

The present study is inspired by the tenth anniversary of the new Hungarian Constitution, known under the name of Fundamental Law, which was adopted in 2011 and entered into force in 2012. In this study we analyse the ten-year old Fundamental Law and its constitutional practice with regard to the important challenges and tasks of the 21st century, namely how the protection of the interests of future generations and the environment are reflected in it. Particularly important elements of the study are (a) the institutional guarantees of the relevant provisions, such as the provisions relating to the Constitutional Court and the Advocate of Future Generations, (b) the concept of GMO-free agriculture in the Fundamental Law, (c) the theses of the Constitutional Court practice on the probibition of retrogression and the precautionary principle, (d) new interpretative frameworks and possibilities arising from other values of the Fundamental Law, such as the provisions on Christian culture, (e) the open questions of interpretation of the Fundamental Law on waste and the environmental liability regime, (f) the priority protection of natural resources, which are the common heritage of the nation, and last but not least (g) the particularly forward-looking integration of the interests of future generations in the rules on public finances and national assets.

Keywords: Hungarian Constitution, future generations, right to a healthy environment, institutional guarantees, protection of natural resources, principle of precaution, non-regression clause.

The new Hungarian Constitution adopted ten years ago, in 2011, known under the name of Fundamental Law and its amendments, as well as the constitutional (especially constitutional court) practice that has undergone significant changes in the recent period, can be considered remarkable from the point of view of protecting future generations, especially in the field of environmental aspects, which is the narrow topic of our study. ${ }^{1}$

János Ede Szilágyi: The Protection of the Interests of Future Generations in the 10-Year-Old Hungarian Constitution, With Special Reference to the Right to a Healthy Environment and Other Environmental Issues. Journal of Agricultural and Environmental Law ISSN 1788-6171, 2021 Vol. XVI No. 31 pp. 130-144, https://doi.org/10.21029/JAEL.2021.31.130

* Professor, PhD, dr. habil., University of Miskolc, Faculty of Law, Department of Agricultural and Labour Law, e-mail: civdrede@uni-miskolc.hu, ORCID: 0000-0002-7938-6860.

** This study has been written as part of the Ministry of Justice programme aiming to raise the standard of law education, but the author did not receive any financial support for his research.

${ }^{1}$ See the comparison of the relevant provisions of the Hungarian Fundamental Law with the German Fundamental Law and the French, Italian and Belgian Constitutions: Szilágyi 2021. 
In this paper, we will attempt, purely on the basis of our own arbitrary selection, to briefly assess the constitutional legislation and constitutional practice of the period that began with the adoption of the Fundamental Law and extended until the finalisation of the manuscript of this paper, i.e. the adoption of the ninth amendment to the Fundamental Law.

Our comments below focus on the related constitutional legislation and the constitutional practice based on it. It is important to note that, in addition to the Parliament and the Constitutional Court (AB), other actors have also played a major role in shaping these, including the President of the Republic ${ }^{2}$ and the Deputy Commissioner for the Environment of the Parliamentary Commissioner for Fundamental Rights (the Ombudsman), the so-called Advocate of Future Generations ${ }^{3}$ (the AFG). The AFG has contributed to all this in an institutionalised way through its core specificities, i.e. the special powers guaranteed by the Fundamental Law and the law on the Commissioner for Fundamental Rights and their deputies, ${ }^{4}$ and the President of the Republic, possibly through the individual role(s) of the person occupying the position.

1. The constitutional foundations for the protection of future generations and the environment are not without precedent in the Hungarian constitutional legislation and practice following the change of regime. ${ }^{5}$ Hungarian public thinking, legislation and practice in the field of environmental protection had a number of major characteristics and results even before the Fundamental Law was adopted. Among those with constitutional relevance, ${ }^{6}$ we wish to mention the following.

\footnotetext{
2 In this specific case, the role of the President of the Republic is also referred to by the Advocate of Future Generations: Bándi 2020a, 18. In this particular case, forming the background of AB Resolution 13/2018, the President of the Republic also introduced a new approach to the interpretation of the law; on this see: Szilágyi 2018a, 84-85. It should also be noted that, like AB Resolution 13/2018, the other major 'green decision' of the Constitutional Court, the 16/2015 AB decision, was also submitted to the Constitutional Court on the initiative of the President of the Republic. In addition to all these specific situations, there may also be cases that are 'invisible' to the public, when the President of the Republic intervenes informally during the preparation and adoption of a particular piece of legislation.

${ }^{3}$ Bándi 2020a, 8-11. It is important to note that, in addition to its internal legal activities, the AFG also has a valuable contribution to make in the international policy and legal dimension; see for example the English summary of the AFG's position of SDGs of 8 May 2018; available at <http://www.ajbh.hu/jnbh-figyelemfelhivasok>

${ }^{4}$ See Act CXI of 2011 on the Commissioner for Fundamental Rights.

5 On the circumstances of the adoption of the Fundamental Law, see also Raisz 2012, 37-70.; Fülöp 2012, 76-87.

${ }^{6}$ It has no constitutional relevance, but because of its international importance, Hungary's involvement in one of the first environmental cases before the International Court of Justice in The Hague could be mentioned: One of the democratic community-forming events of our regime change was the social movement and protests against the Bős-Nagymaros hydroelectric power plant, an initiative with broad social support that led the Hungarian side to reconsider its original ideas regarding the planned hydroelectric power plant. The resulting dispute has become one of the most famous environmental disputes in public international law and was the basis for the judgment of the International Court of Justice in The Hague. In the legal dispute, the
} 
(a) The constitutional basis of the right to a healthy environment and the protection of the environment, namely the right to a healthy environment and the right to the highest attainable standard of physical and mental health, was provided for by Articles 18 and 70/D of the former Constitution ${ }^{7}$ as amended in 1989. Originally, "in 1989, Article 18 of the "Hungarian Constitution was intended to be declarative rather than normative in nature. However, the text of Article 18 [...] has been given normative content by the practice of the Constitutional Court.'\$ In 2006, László Fodor, who elaborated the related jurisprudence of the Constitutional Court in monographic form, captured the role of the Constitutional Court in the development of the normative content of the right to a healthy environment as follows: "Because, of course, the content of the right to the environment had not been clarified before [...] the Constitutional Court had a rather wide room for manoewure in interpreting and giving content to the right to the environment [...] We regret that, in the field of dogmatics, the Court only exercised this freedom for about three years and has not developed the content of the law in recent years with a requirement of principle. "') The precedent-setting practice of the Constitutional Court referred to by László Fodor was based on AB Resolution 28/1994 (20 May). One of the central elements of this decision is the non-regression clause, which is essentially a prohibition on the deterioration of the level of protection previously achieved. ${ }^{10}$ However, the relationship between the right to a healthy environment, environmental protection and the Constitutional Court did not end with the Constitutional Court's interpretation of the relevant paragraphs of the Constitution. In all the - relatively few ${ }^{11}$ - cases in which the Constitutional Court has dealt with the right to a healthy environment and other constitutional relevance of environmental protection, the Constitutional Court has also undergone a special change of form: "The Constitutional Court basically decides on questions of law, but some of its decisions on environmental issues [...] have turned the body into a court of facts, since it has not only provided solutions to the legislation under examination, but also to the situations and conflicts that have arisen. An interesting feature of the Constitutional Court proceedings is that in some of the environmental cases, the panel also conducted a technical or factual evidentiary hearing. This solution was partly successful [...] and partly resulted in errors or debatable elements in the reasoning." 2

Hungarian side based its claims to a large extent on environmental aspects, and the environmental approach also played a decisive role in the final court decision.

${ }^{7}$ Act XX of 1949 the Constitution of the Republic of Hungary

${ }^{8}$ Fodor 2006, 193.

${ }^{9}$ Fodor 2006, 194-195. For a discussion of all this, see also Fodor 2006, 157-163.

10 The interpretation of the Hungarian AB declaring the prohibition of retrogression, which is also forward-looking in international comparison, has been widely recognised at the professional level; this was also considered important to be recorded in the AB Resolution 16/2015 (Section 81). See Bándi 2017, 159-181.

11 László Fodor refers to these quantitative aspects in 2006: "However, in evaluating the (in itself forward-looking) judgments of the Constitutional Court, we must add that the reasoning used could certainly serve as a basis for the annulment of hundreds of laws," if the cases had reached the Constitutional Court; Fodor 2006, 158. He makes a similar point in 2014: "In practice, the [AB] rarely applies it, and when it can, it tends to seek. formal grounds for annulling the challenged legislation"; Fodor 2014, 110.

12 Fodor 2006, 162. In our view, the same will be true for the Constitutional Court in the future, for example in the context of AB Resolution 13/2018. 
(b) The Parliamentary Commissioner for Future Generations (CFG), functioning in the form of a separate Parliamentary Commissioner (i.e. Ombudsman), was a kind of preceding concept to the deputy of the Commissioner for Fundamental Rights, responsible for the protection of the interests of future generations i.e., the AFG mentioned above (Article 30 of the Fundamental Law), and was expressly named in the Fundamental Law. The CFG was already established before the adoption of the Fundamental Law. ${ }^{13}$ This has led to the creation of an internationally exemplary concept, which has already made significant progress in putting the right to a healthy environment into practice in a short space of time. In fact, it was the Commissioner's own contribution to the drafting of the environmentally relevant provisions of the Fundamental Law that he considered to be one of his greatest successes. ${ }^{14}$

(c) The concept of agriculture free of genetically modified organisms (GMOs) (Article XX of the Fundamental Law), a specific element of the Fundamental Law, can be traced back to the time before the adoption of the Fundamental Law - and essentially to a political consensus, the important embodiment of which is Parliamentary Resolution 53/2006 (November 29). All this political determination has led to one of the EU's most peculiar constitutional GMO legislation at the time of the drafting of the Fundamental Law.

2. The Fundamental Law adopted in 2011 brought with it - in terms of environmental regulation ${ }^{15}$ - what the Constitution already contained - namely, by inserting the text of Articles XVIII and 70/D of the Constitution (which are essentially identical in substance to our topic) - and adding some new provisions, including some of great importance, in substance (see below). ${ }^{16}$ From the very beginning, however, the question has been raised as to what extent the case law of the Constitutional Court prior to the adoption of the Fundamental Law can be applied to the interpretation of the provisions of the Fundamental Law that show a textual similarity. The CFG wanted to settle this issue early on, arguing in favour of maintaining the previous interpretation of the Constitutional Court. ${ }^{17}$ In this case, however, the fourth amendment to the Fundamental Law has created a new situation by stating that Constitutional Court decisions taken before the entry into force of the Fundamental Law are null and void. This provision was then shaded by the AB Resolution 13/2013, generally ("The Constitutional Court always examines the applicability of the arguments set out in previous decisions on a case-by-case basis, in the context of the specific

\footnotetext{
${ }^{13}$ For the discourse on institution building, see Sólyom 2001, 14. Fodor 2008, 47-52.; Majtényi 2008, 25-26. See also the previous opinion of László Fodor: Fodor 2006, 198. (Footnote 5). On the current situation and status of the Green Ombudsman, see in particular Szabó 2015, 6-24.; Fülöp 2016, 195-212.; Bándi 2020a, 8-11.

${ }^{14}$ Fülöp 2012, 76.

${ }^{15}$ For the analysis see Bándi 2013, 67-92.; Bándi 2016, 7-25.; Bándi 2019, 339-382.; Fodor 2011; Farkas Csamangó 2017, 11-12.

16 For the same conclusion, see the Resolution 258/2011 of the CFG on the State's responsibility under the environmental and sustainability provisions of the new Fundamental Law, Sections 3 and 12-13. Similarly Bándi 2020a, 8.

${ }^{17}$ Resolution of the CFG 258/2011, Section 11.
} 
case."'18), and $\mathrm{AB}$ Resolution 3068/2013 in the specific context of the right to the environment. ("The text of the Fundamental Law is identical to the text of the Constitution with regard to the right to a healthy environment, and therefore the findings of the Constitutional Court in its previous decisions may be considered as applicable in the interpretation of the right to a healthy environment.'"19)

3. As we have pointed out, Article XX of the Fundamental Law ${ }^{20}$, in addition to a few elements to be elaborated later, includes - in its essence - all that was previously included in Article 70/D of the Constitution, namely the right to physical and mental health and the protection of the environment as one of the means of its realisation. Likewise, Article XXI (1) of the Fundamental $\mathrm{Law}^{21}$ essentially transposes the right to a healthy environment enshrined in Article 18 of the Constitution. ${ }^{22}$ The basic resolution interpreting the right to a healthy environment in the practice of today's Constitutional Court is the AB Resolution 16/2015 (5 June), which itself refers to the interpretation of the AB Resolution 28/1994 - and several other Constitutional Court resolutions prior to the adoption of the Fundamental Law - essentially adopting its (their) cardinal provisions. ${ }^{23}$ Accordingly, AB Resolution 16/2015 adopts the non-regression clause from the previous practice of the Constitutional Court. ${ }^{24}$ At the same time, AB Resolution $16 / 2015$ puts the previous interpretation of the right to a healthy environment in a new context, given that the Fundamental Law has introduced several new elements into its text (see below), in addition to the previous regulatory framework (Articles 18 and $70 / \mathrm{D}$ of the Constitution), in particular Article P), which guarantees a high level of protection of natural resources. ${ }^{25}$ With this in mind, the Constitutional Court has

\footnotetext{
18 AB Resolution 13/2013. Section 34.

19 AB Resolution 3068/2013. Section 46.

${ }^{20}$ Fundamental Law, Article XX: "(1) Everyone shall have the right to physical and mental health (2) Hungary shall promote the effective application of the right referred to in Paragraph (1) by an agriculture free of genetically modified organisms, by ensuring access to bealthy food and drinking water, by organising safety at work and healthcare provision, by supporting sports and regular physical exercise, as well as by ensuring the protection of the environment"

${ }^{21}$ Fundamental Law, Article XXI: "(1) Hungary shall recognise and give effect to the right of everyone to a bealthy environment. (2) Anyone who causes damage to the environment shall be obliged to restore it or to bear the costs of restoration, as provided for by an Act (3) The transport of pollutant waste into the territory of Hungary for the purpose of disposal shall be probibited."

22 On the international dimension of environmental rights, see: Marinkás 2020, 133-170.; Bándi 2021, 179-206.; Kecskés 2021, 207-220.

23 AB Resolution 16/2015, Section 80-86. E.g., the interpretation of the fundamental right to a healthy environment has been transposed as follows: "Although according to the [AB] it is a fundamental right, but this right does not have a subjective side [...] The right to the environment therefore does not mean that everyone - even against the state - can formulate a claim and enforce it directly (through litigation) before the courts, demanding an environmental condition that meets their subjective needs. As the literature points out: making the requirements subjective would lead to unfulfillable expectations of the state, and for this reason (or because of the indeterminate content of the right) the right to the environment is not recognised as a subjective right anywhere in Europe." Fodor 2014, 106.

${ }^{24}$ AB Resolution 16/2015, Section 109.

${ }^{25}$ Fundamental Law, Article P): “(1) Natural resources, in particular arable and, forests and the reserves of water, biodiversity, in particular native plant and animal species, as well as cultural assets shall form the common
} 
already applied the prohibition of retrogression in a new situation, namely in the case of rules on the regulation of organisations, ${ }^{26}$ unprecedented in previous Constitutional Court practice. Previously, the non-regression clause applied only to substantive and procedural rules.

4. In essence, with reference to the constellation of Article XXI and Article P), which creates a new situation, a further interpretation of constitutional law (almost legislation) was created at the level of principle, namely the conceptualisation of the precautionary principle as a Constitutional Court standard. ${ }^{27}$ The "principle of precaution does not only apply in the context of the probibition of retrogression, but also in its own right." 28 When applied in conjunction with the principle of non-regression, "where a regulation or measure may affect the state of the environment, it is for the legislator to demonstrate that the regulation does not constitute a step backwards",29 and "in accordance with the principle of precaution, the actual deterioration of the environment is not necessary for the non-regression clause to be infringed, but the risk of deterioration alone justifies a breach of the probibition." 30 In the case of autonomous application, "in the case of measures which do not formally constitute a retrogression but which may affect the state of the environment, the measure is also limited by the principle of precaution, in the context of which the legislator has a constitutional obligation to give due weight to the risks which it considers scientifically likely or certain to occur when making its decision."'31 The practice of the Constitutional Court related to the interpretation of the precautionary principle may reinforce the specific functioning of the Constitutional Court, which was already mentioned by László Fodor in the context of the previous practice, namely that the Constitutional Court conducts in such cases not only legal questions but also professional or factual evidence. At least the basic decision of the principle of precaution - issued after a number of precedents - ${ }^{32}$ AB Resolution 13/2018 (4 September), ${ }^{33}$ suggests that. In our view, the new principle also creates an opportunity for the Constitutional Court to decide on the applicability of new, risky technologies - requiring legal regulation; that is, with some (perhaps oversimplified) simplification, if nuclear technology, genetic engineering or even mobile technology had been introduced by law in Hungary for the first time after the adoption of $A B$ Resolution $13 / 2018$, it is far from certain that all of these would have passed the test of

\footnotetext{
heritage of the nation; it shall be the obligation of the State and everyone to protect and maintain them, and to preserve them for future generations (2) The limits and conditions for acquisition of ownership and for use of arable land and forests necessary for achieving the objectives referred to in Paragraph (1), as well as the rules concerning the organisation of integrated agricultural production and concerning family farms and other agricultural holdings shall be laid down in a cardinal Act."

26 AB Resolution 16/2015, Section 110-111.

27 AB Resolution 13/2018, Section 20.

28 AB Resolution 13/2018, Section 20.

${ }^{29}$ AB Resolution 13/2018, Section 20.

30 AB Resolution 13/2018, Section 65.

31 AB Resolution 13/2018, Section 20.

32 On these precedent resolutions, see Szabó 2018, 485-499.; Szilágyi 2018a, 79-82.

${ }^{33}$ For an analysis of this, see also: Szilágyi 2019b, 88-112.; Szabó 2019, 67-83.; Hohmann \& Pánovics 2019, 305-309.; Kecskés 2020, 371-382.
} 
a strictly applied precautionary measure. ${ }^{34}$ In view of all this, one of the most exciting questions for us in the context of the constitutional revision of the last few years has been whether the legislator intends to react to the established or emerging practice of the Constitutional Court by amending the text of the Fundamental Law in some way. At this stage, it seems that the legislator has not taken this opportunity.

5. Article XX (2) of the Fundamental Law contains several new instruments to enforce the right to physical and mental health. These include, for example, in addition to 'ensuring access to healthy food and drinking water', 35 which is also considered significant, the provision on 'GMO-free agriculture' (hereafter: the concept of 'GMOfree agriculture'). The interpretation of the latter in particular has posed multiple challenges for those seeking answers when applying the concept. ${ }^{36}$ The cardinal questions are - among many others ${ }^{37}$ - (a) the scope of activities or products covered by the provisions, (b) the binding force of these provisions, and (c) their relationship with EU law. Without disputing the assessments of other authors on the subject, our interpretation of the provisions of the Fundamental Law on GMO-free agriculture is as follows. In our view, the exact nature of this provision of the Fundamental Law is unclear. It may be noted, however, that this provision is not a directly enforceable probibition (but rather a guideline for public policy makers). Initially, this provision was mainly invoked by Hungarian policy makers in the context of limiting the public cultivability of GM crops (a narrow interpretation). In other words, based on this narrow interpretation, the presumed intention of the legislator was not contradicted by the fact that GM products (e.g. food) imported from abroad should be placed on the tables of Hungarian consumers. However, for some years now, it seems that the category of GMO-free agriculture has been increasingly being used by policy makers to include other issues beyond the issue of GMO intercultivation, such as the aspiration to create the conditions for GMO-free food production in Hungary (a broader interpretation of the concept). In addition to the above interpretative aspect, the concept of GMO-free agriculture in the Fundamental Law also raises the question of whether the latest techniques (so-called gene or genome editing technologies, as a kind of GMO 2.0 technologies) fall within its scope at all. After the related EU court ruling ${ }^{38}-$ following its logic - the Hungarian Ministry of Agriculture finally interpreted that GMO 2.0 is also covered by the concept of GMO-free agriculture in the Fundamental Law.39 However, we have to agree with Gyula Bándi that the concept of genetic engineering may in the

\footnotetext{
${ }^{34}$ For a more detailed discussion of all these arguments, see Szilágyi 2018a.

${ }^{35}$ For an analysis of all this in relation to the right to water, see Szilágyi 2018b, 259-272.

36 See on this Szilágyi, Raisz \& Kocsis 2017, 167-175.; Fodor 2014, 113-114.; Hegyes \& Varga 2020, 104-117.; Tahyné Kovács 2015, 88-99.; Téglásiné Kovács 2015, 300-319.; Téglásiné Kovács 2017, 147-164.; C.f. Raisz 2015, 275-286.

${ }^{37}$ Raisz \& Szilágyi 2021.

38 Judgment of 25 July 2018 in the case C-528/16, Confédération paysanne et al kontra Premier ministre, Ministére de l'Agriculture, de l'Agroalimentaire et de la Foret (HL C 328., 2018.9.17., pp. 4-5). For the analysis of the case, see: Fodor 2018, 42-64.

${ }^{39}$ For details, see also Raisz \& Szilágyi 2021.
} 
future depend in a significant way on the relevant EU legislative trends and therefore a redefinition of the concept in the basic law may be unavoidable. ${ }^{40}$

6. Article XXI (2) and (3) of the Fundamental Law introduce new elements, supplementing the right to a healthy environment, which is provided for in Article XXI (1) of the Fundamental Law and was already provided for in Article 18 of the Constitution. Pursuant to Article XXI (2) of the Fundamental Law, "Anyone who causes damage to the environment shall be obliged to restore it or to bear the costs of restoration, as provided for by an Act," while pursuant to Article XXI (3) of the Fundamental Law, "The transport of pollutant waste into the territory of Hungary for the purpose of disposal shall be probibited." Several comments on the provisions have been made in the literature and by the CFG/AFG, and it should be noted at the outset that none of these comments challenged the strictness of waste management or the enforcement of a higher level of environmental responsibility or the legislative commitment to this end, but were more to do with the way they were formulated and the way they could be enforced. Thus, for example, Professor Gyula Bándi and the AFG do not consider them sufficiently "practical"..41 First of all, it should be pointed out - and this mainly concerns the current Article XXI (2) of the Fundamental Law - that the CFG has already proposed during the preparation of the Fundamental Law to include the polluter pays principle, the precautionary principle and the principle of precaution in the text of the Fundamental Law. ${ }^{42}$ Although neither of these principles is stated expressis verbis ${ }^{43}$ in the text of the Fundamental Law ${ }^{44}$ - in our view - the principle of responsibility has been formulated in a way in Article XXI (2) of the Fundamental Law; Professor Bándi called it "a narrowed conception of the polluter pays principle"45, and according to Professor Fodor, this "rule merely refers to the framework of environmental liability". 46 As an important antecedent of Article XXI (3) of the Fundamental Law - as an explanation for its adoption we consider it important to mention the German garbage issue, the essence of which was that a huge amount of waste from Germany was illegally dumped on the territory of Hungary. In the light of all this, it is perhaps understandable that the policymaker wanted to respond to the issue with the necessary decisiveness. Nor do representatives of environmental law in Hungary dispute the purpose of this provision: According to Professor Bándi, ${ }^{47}$ on the one hand, it would have been sufficient to regulate the issue in the Waste Act alone (the legislator has already done so); on the other hand, we note that regulating the issue in the Fundamental Law provides so much more security than regulating it in the Waste Act alone, since the Fundamental Law can only be amended

40 Bándi 2020a, 15. It made specific proposals for amendments, essentially based on natural science aspects: Darvas 2018.

${ }^{41}$ Bándi 2020a, 16.

42 Fülöp 2012, 82.

${ }^{43}$ In our opinion, however, the basic concept of GMO-free agriculture in the Fundamental Law can be interpreted as a regulation that contains the precautionary principle in a hidden form.

44 We are aware that with this statement we contradict the JNO's legal analysis, see Position 258/2011, Sections 8 and 11 of the CFG.

${ }^{45}$ Bándi 2020a, 16.

${ }^{46}$ Fodor 2014, 114.

${ }^{47}$ Bándi 2020a, 16. 
by a two-thirds majority of the members of the Parliament. On the other hand, Professor Bándi also drew attention to the inaccuracies in the wording of the Basic Law; we can identify with these remarks - without going into details - ourselves. In addition to the above, Professor Fodor also considers compatibility with EU law to be an important aspect of Article XXI (3) of the Fundamental Law, noting that "it is unprecedented in Europe and, in its content, as waste is a commodity in the EU, it is a provision aimed at restricting the free movement of goods. In terms of its binding force, of course, it is not directly enforceable either. "'48 In view of the above arguments, in relation to Article XXI (2)-(3) of the Fundamental Law, the AFG de lege ferenda proposes either to clarify and reformulate the provisions or to delete them from the text of the Fundamental Law. ${ }^{49}$ In relation to this proposal, we would argue in favour of the former, i.e. a more precise wording of the basic law, and would rather interpret the simple deletion of the provisions as a kind of retrograde step. However, it would be beyond the scope of this study to explain in which direction we believe the relevant two paragraphs of the Fundamental Law should be clarified; for example, the expressis verbis naming of the polluter pays principle would also require a substantive decision - and a corresponding preliminary assessment - since the inappropriate naming of the polluter pays principle could also lead to further difficulties of interpretation.

7. The Preamble to the Fundamental Law also touches on the subject of our study in several respects. Most often analysed in this context is its Call 7, which states that "We commit to promoting and safeguarding our heritage, [...] along with all man-made and natural assets of the Carpathian Basin. We bear responsibility for our descendants; therefore we shall protect the living conditions of future generations by prudent use of our material, intellectual and natural resources."The significance of the provision, Professor Fodor noted, is that "[this] wording is strongly reminiscent of the principle of sustainable development, even if it does not explicitly name the principle itself.' ${ }^{50}$ In addition to Call 7,51 the environmental relevance of other provisions of the Preamble is linked to Christian morality by the AFG. We can agree with him, but we also note that the Christian culture and set of values explicitly expressed in the text of the Preamble and in Articles R) and XVI can be interpreted as an important innovation of the Fundamental Law and as a paragraph of the Fundamental Law that embodies the protection of the interests of future generations. Professor Bándi draws attention to a similar connection in several of his studies, ${ }^{52}$ in which he analyses human rights, especially the right to the environment and the protection of future generations, and their relationship with Christian beliefs and ideals. Professor Bándi sees correctly interpreted Christian teachings as an important pillar of environmental protection.

\footnotetext{
${ }^{48}$ Fodor 2014, 114.

${ }^{49}$ Bándi 2020a, 17.

${ }^{50}$ Fodor 2014, 112.

${ }^{51}$ For a different reason, Dávid Hojnyák proposes to supplement Call 7 with regard to the prominent role of rural communities; on this issue see Hojnyák 2019, 58-76.; Hojnyák 2020, 174-185.; Szilágyi 2019a, 451-470.

52 The latest of these is the following: Bándi 2020b, 9-33. For a background to this study, see for example Bándi 2013, 67-92.; Cf. Bányai 2019, 298-323.
} 
In this respect, Christian culture and Christianity, which is expressed expressis verbis in the text of the Fundamental Law, ${ }^{53}$ can also be seen as an institution that helps to protect the interests of future generations and embodies the traditional element of environmental protection. In this context, the amendment of Article XVI (1) of the Fundamental Law with the twist of upbringing of children in accordance with values based on Christian culture could be another forward-looking change for the benefit of future generations.

8. In connection with Article P) of the Fundamental Law, it has already been mentioned that, in addition to Article XXI (1) of the Fundamental Law, this article has provided the basis for the numerous innovative interpretations of the Constitutional Court in 2015 and thereafter ${ }^{54}$ (e.g. the principle of precaution). However, Article P) of the Fundamental Law may be relevant in other respects. Thus, in the case of the "natural resources' turn of phrase it refers to - such as arable land, forests and water resources, biodiversity 55 - the legislator has provided that they are the common heritage of the nation. (a) In our view, the common heritage of the nation is a kind of contrast with the category of 'common heritage of mankind' (under which all the peoples of the world could claim the exploitation of a given natural resource), as known in international law. (b) The word 'beritage' in the common heritage of the nation also indicates that the legislator did not refer to the natural resources named in the Fundamental Law (b1) as objects of mere commercial transactions (goods, capital, etc.), but also takes into account their other, vital functions (b2) and also intergenerational aspects (namely that they must be exploited by each generation in the interests of future generations). (c) It is important to underline that the category of the common heritage of the nation does not coincide with another category of the Fundamental Law, namely "national assets", which, incidentally, is not the same as the category of the same name in the preamble to Act LIII of 1995 on the General Rules for the Protection of the Environment (Environmental Protection Act). (c1) While the category of national assets in the Fundamental Law refers to state and municipal property (or assets), (c2) the category of 'national assets' in the Environmental Protection Act can be seen as a confrontation with the theory that identifies environmental assets as unowned things. The category of national assets in the Environmental Protection Act cannot be identified with any one form of ownership, but includes the values that are decisive for the country, regardless of who owns them.

\footnotetext{
53 This is mentioned four times in the preamble and in the main text of the Fundamental Law, as "Christian Europe", "Christianity", "Christian culture". In addition, the framing text of the Fundamental Law also mentions "God" twice.

54 The Constitutional Court has reached a similar conclusion, and in relation to his active role in recent years, Bándi, 2020a, 17.

55 "Although Article P) (1) does not specify the nature of the natural assets to be protected (see the term 'specifically'), it does specify what environmental protection as a public and private obligation actually means: 1 . protection; 2 . preservation; 3 . conservation for future generations." AB Resolution 16/2015, Section 92. Fodor, 2013, 337-338., provides a valuable interpretation of the legal provision
} 
9. One of the features of our Fundamental Law is the protection of "national assets', managed with the needs of future generations in mind, and of budgetary operations that serve a kind of 'financial sustainability'. The former is centrally regulated by Article 38 (1) of the Fundamental Law, which states: "The property of the State and of local governments shall be national assets. The management and protection of national assets shall aim at serving public interest, meeting common needs and preserving natural resources, as well as at taking into account the needs of future generations." From the point of view of sustainability, Professor Bándi ${ }^{56}$ considers the twists and turns of Article N (1) of the Fundamental Law on the budget to be particularly significant: "Hungary shall observe the principle of balanced, transparent and sustainable budget management." To complement all this, we also consider Articles 36-37 of the Fundamental Law to be equally forward-looking, which, among other things, are intended to set a maximum level of public debt, and which, by virtue of their purpose, can also be interpreted as meaning that current generations should not financially incapacitate future generations by a possible credit trap. This interpretation is also supported by the explanatory memorandum to Article 36 of the Fundamental Law, ${ }^{57}$ according to which the Fundamental Law provides for rules to prevent the growth of public debt "with a view to the responsibility for the situation of future generations"; similarly, the legislator justifies Article 37, i.e. that the Fundamental Law introduces strict budgetary rules "in order to avoid imposing an intolerable burden on future generations by giving excessive priority to current needs or interests." We believe that this clearly demonstrates the legislative intention to avoid indebtedness of future generations. Article 36 (4) of the Fundamental Law sets the ceiling for public debt at half of the 'total gross domestic product. ${ }^{8}$ Given the fact that, in the time since the adoption of the Fundamental Law, the situation provided for in Article $36((4))$ has not yet arisen (i.e. the level of public debt has not fallen below the amount of half of the total gross domestic product), the situation provided for in Article $36((5))$ of the Fundamental Law has prevailed until now, i.e., "As long as state debt exceeds balf of the Gross Domestic Product, the National Assembly may only adopt an Act on the central budget which provides for state debt reduction in proportion to the Gross Domestic Product." Given the difficult situation of the

\footnotetext{
${ }^{56}$ Bándi 2020a, 13.

${ }^{57}$ Fundamental Law, Article 36: "[...] (4) The National Assembly may not adopt an Act on the central budget as a result of which state debt would exceed half of the Gross Domestic Product (5) As long as state debt exceeds half of the Gross Domestic Product, the National Assembly may only adopt an Act on the central budget which provides for state debt reduction in proportion to the Gross Domestic Product. (6) Any derogation from the provisions of Paragraphs (4) and (5) shall only be allowed during a special legal order and to the extent necessary to mitigate the consequences of the circumstances triggering the special legal order, or, in case of an enduring and significant national economic recession, to the extent necessary to restore the balance of the national economy."

58 Article 37 (6) of the Fundamental Law, supplementing this rule, stipulates that the method of calculation of public debt and total gross domestic product shall be laid down in a law (namely Act CXCIV of 2011 on the Economic Stability of Hungary (Economic Stability Act)). In this context - as a digression - we consider it important to note that both the explanatory memorandum of the Fundamental Law and the Economic Stability Act use the term 'gross domestic product' (or GDP for short) instead of the term 'total gross domestic product', which seems more economically accurate, thus making the GDP category, used as a general parameter of economic development, the benchmark for combating excessive public debt.
} 
national economy due to the epidemic, we believe that an important question is how Article 36 (5) and (6) of the Fundamental Law will be applied. According to the latter, "Any derogation from the provisions of Paragraphs (4) and (5) shall only be allowed during a special legal order and to the extent necessary to mitigate the consequences of the circumstances triggering the special legal order, or, in case of an enduring and significant national economic recession, to the extent necessary to restore the balance of the national economy." In our view, the real test of Article 36 (4) - (6) of the Fundamental Law - which is, by the way, very forward-looking for future generations - will be the present period, and only in the light of the experience gained in this period can we really draw conclusions on the practical applicability - and possible future clarification - of the relevant legal provision. However, it is difficult for us to imagine protecting the interests of future generations without a level of public debt that is manageable and not exceeded, i.e. without a form of financial sustainability.

For reasons of space, it was not possible to analyse the Fundamental Law and the related case law in detail in this study. In view of this, we have only been able to focus on certain areas that we have selected and have tried to formulate our ideas, assessing the existing legal situation in the interests of future generations and the protection of the environment, and trying to make forward-looking comments on how to improve this situation. Even in its present state, we believe that the now ten-year-old Fundamental Law already regulates the protection of the interests of future generations and the protection of the environment at a high level, and in many respects in a way that is a model for others. With this in mind, it would be important to ensure that the spirit of the Fundamental Law is applied as fully as possible in its implementation. 


\section{Bibliography}

1. Bándi Gy (2013) A környezethez való jog értelmezése a fenntartható fejlődési stratégia és az Alaptörvény fényében, Acta Humana 1(1), pp. 67-92, https:// folyoirat.ludovika.hu/index.php/actahumana/article/view/3028 [29.10.2021]

2. Bándi Gy (2016) Környezethez való jog - újratöltve, Acta Humana 4(2), pp. 7-25, https:// folyoirat.ludovika.hu/index.php/actahumana/article/view/2504 [29.10.2021]

3. Bándi Gy (2017) Környezeti értékek, valamint a visszalépés tilalmának értelmezése, Iustum Aequum Salutare 13(2), pp. 159-181.

4. Bándi Gy (2019) Környezethez való jog, in: Schanda B, Balogh Zs (eds.) Alkotmányjog - alapjogok, Pázmány Press, Budapest, pp. 339-382.

5. Bándi Gy (2020a) Interests of Future Generations, Environmental Protection and the Fundamental Law, Journal of Agricultural and Environmental Law 15(29), pp. 7-22, doi: https://doi.org/10.21029/JAEL.2020.29.7

6. Bándi Gyula (2020b) A Teremtés védelme és az emberi jogok, Acta Humana 8(4), pp. 9-33, doi: https://doi.org/10.32566/ah.2020.4.1

7. Bándi Gy (2021) Az Emberi Jogok Európai Egyezménye, a Szociális Karta és a környezeti jogok, Acta Humana 9(2), pp. 179-206, doi: http:/ / doi.org/10.32566/ah.2021.2.8

8. Bányai O (2019) The Foundation of an Upcoming Civilization Able to Reach its Fulfillment Within the Ecological Limits of the Earth: The Eternal Order, World Futures 75(5-6), pp. 298-323, doi: https://doi.org/10.1080/02604027.2019.1591812

9. Darvas B (2018) A nagy precíziós buli - 7. rész: Hazai törvények és hiányosságaik, Atlátš́ó, 5 September, https://darvasbela.atlatszo.hu/2018/09/05/a-nagyprecizios-buli-7-resz-hazai-torvenyek-es-hianyossagaik/ [29.10.2021]

10. Farkas Csamangó E (2017) Környezetjogi szabályozások, Szegedi Tudományegyetem ÁJK ÜJI, Szeged.

11. Fodor L (2006) Környezetvédelem az. Alkotmányban, Gondolat Kiadó - Debreceni Egyetem ÁJK, Budapest.

12. Fodor L (2008) A jövő nemzedékek jogai, Fundamentum 12(1), pp. 47-52.

13. Fodor L (2011) Természeti tárgyak egy új alkotmányban, Pázmány Law Working Papers 21, http://plwp.eu/docs/wp/2012/2011-21.pdf [29.10.2021]

14. Fodor L (2013) A víz az Alaptörvény környezeti értékrendjében, Publicationes Universitatis Miskolcinensis Sectio Juridica et Politica 31, pp. 329-345.

15. Fodor L (2014) Körmyezetjog, Debreceni Egyetemi Kiadó, Debrecen.

16. Fodor L (2018) A precíziós genomszerkesztés mezőgazdasági alkalmazásának szabályozási alapkérdései és az elővigyázatosság elve, Pro Futuro 8(2), pp. 42-64.

17. Fülöp S (2012) Az egészséges környezethez való jog és a jövő nemzedékek érdekeinek védelme az Alaptörvényben, in: Csák Cs (ed.), Jogtudományi tanulmányok a fenntartható természeti eróforrások témakörében, Miskolci Egyetem, Miskolc, pp. 76-87. 
18. Fülöp S (2016) The institutional representation of future generations, in: Bos $G$ \& Düvell M (eds.) Human Rights and Sustainability, Routlege, London, pp. 195-212, doi: https://doi.org/10.4324/9781315665320-15

19. Hegyes P \& Varga Cs (2020) Fundamental Law pillars of sustainable agriculture, Journal of Agricultural and Environmental Law 15(29), pp. 104-117., doi: https://doi.org/10.21029/JAEL.2020.29.104

20. Hohmann B \& Pánovics A (2019) Vízvédelem és elővigyázatosság, Jura 25(1), 305-309.

21. Hojnyák D (2019) Az agrárszabályozási tárgyak megjelenése az Európai Unió tagállamainak alkotmányaiban[...], Miskolci Jogi Szemle 14(2), pp. 58-76.

22. Hojnyák D (2020) Vidék az alkotmányban?, Miskolci Jogi Szemle 15(2), pp. 174-185.

23. Kecskés G (2020) The Hungarian Constitutional Court's Decision on the Protection of Groundwater, Hungarian Yearbook of International Law and European Law 8(1), pp. 371-382, doi: https://doi.org/10.5553\%2FHYIEL\%2F266627012020008001022

24. Kecskés G (2021) A környezeti jogok értelmezése az Emberi Jogok Európai Egyezményébe foglalt jogok körében, Acta Humana 9(2), pp. 207-220, doi: http://doi.org/10.32566/ah.2021.2.9

25. Majtényi B (2008) A jövő nemzedékek és a természeti tárgyak köztársasága?, Fundamentum 12(1), pp. 17-28.

26. Marinkás Gy (2020) The Right to a Healthy Environment as a Basic Human Right, Journal of Agricultural and Environmental Law 15(29), pp. 133-170, doi: https://doi.org/10.21029/JAEL.2020.29.133

27. Raisz A (2012) A Constitution's Environment, Environment in the Constitution, Est Europa - La Revue különszám(1), pp. 37-70.

28. Raisz A (2015) GMO as a weapon: a.k.a. a new form of aggression?, Hungarian Yearbook of International Law and European Law 3(1), pp. 275-286.

29. Raisz A \& Szilágyi J E (2021) A géntechnológiai tevékenység jogi szabályozása, in: Raisz A (ed.) Környezetjog: különös rész, Miskolci Egyetemi Kiadó - ME ÁJK, Miskolc, megjelenés alatt.

30. Sólyom L (2001) Az ombudsman „alapjog-értelmezése” és „,normakontrollja”, Fundamentum 5(2), pp. 14-23.

31. Szabó M (2015) National institutions for the protection of the interests of future generations, e-Pública 2(2), pp. 6-24.

32. Szabó M (2018) Importance of the legal protection of biological diversity, Hungarian Yearbook of International Law and European Law 6(1), pp. 485-499.

33. Szabó M (2019) The Precautionary Principle in the Fundamental Law of Hungary, Hungarian Yearbook of International Law and European Law 7(1), pp. 67-83.

34. Szilágyi J E (2018a) Az elővigyázatosság elve és a magyar alkotmánybírósági gyakorlat, Miskolci Jogi Szemle 13(2/2), pp. 76-91.

35. Szilágyi J E (2018b) Vizszemléletü kormányzás - viápolitika - vizjog, Miskolci Egyetemi Kiadó, Miskolc.

36. Szilágyi J E (2019a) A vidéki közösség, illetve a vidék sui generis alaptörvényi meghatározása, Publicationes Universitatis Miskolcinensis Sectio Juridica et Politica 37(2), pp. 451-470. 
37. Szilágyi J E (2019b) The precautionary principle's 'strong concept' in the case law of the constitutional court of Hungary, Lex et Scientia 26(2), pp. 88-112.

38. Szilágyi J E (2021) Some values and guarantees in the ten-year-old Hungarian Constitution, with a look at the constitutional arrangements of the countries founding the European integration, Central European Journal of Comparative Law 2(2), pp.

39. Szilágyi J E, Raisz A \& Kocsis B E (2017) New dimensions of the Hungarian agricultural law in respect of food sovereignty, Journal of Agricultural and Environmental Law 12(22), pp. 160-201, doi: https://doi.org/10.21029/JAEL.2017.22.160

40. Tahyné Kovács Á (2015) Gedanken zur verfassugsrechtlichen Interpretierung der gesetzlichen Regelung der GVOs in angesichts der Verhandlungen der neuen GVO Verordnung der EU und des TTIP, Journal of Agricultural and Environmental Law 10(18), pp. 72-104.

41. Téglásiné Kovács J (2015) A GMO-mentes Alaptörvény hatása a mezőgazdaságra - különös tekintettel a visszaszerzett EU tagállami szuverenitásra és a TTIP-re, in: Szalma J (ed.) A Magyar Tudomány Napja a Délvidéken 2014, VMTT, Újvidék, pp. 300-319.

42. Téglásiné Kovács J (2017) Az Alaptörvény GMO-mentes mezőgazdaságra vonatkozó rendelkezése, in: Cservák Cs \& Horváth A (eds.) Az adekvát alapjogvédelem, Porta Historica, Budapest, pp. 147-164. 